\title{
Analysis of factors affecting production costs and profitability of milk and dairy products in Turkey
}

\author{
Ahmet Cumhur AKIN ${ }^{1 *}$ (D), Yavuz CEVGER ${ }^{2}$
}

\begin{abstract}
White cheese, kashar cheese, yogurt, and ayran are among the most common products produced by the dairy industry in Turkey. The present study determined the production cost of $1 \mathrm{~kg}$ of these packaged products as well as the financial implications on their distribution and the total cost. The study also estimated the cost factors affecting the profitability of the products by identifying the cost differences between production regions and scales, using a mean regression model for each product. The study used the data collected through a survey involving 15 dairy plants of three different sizes located in five different regions and involved in raw milk production. The study found a 2 -year average capacity utilization rate of the businesses to be $68.80 \%$. The $R^{2}$ of the analyzed products using the backward multiple regression model was 0.874 and above $(p<0.001)$. In conclusion, the regression analysis demonstrated that the major factors affecting profitability were the quantity of raw milk contained in the product, the sale price of the product, and the purchase price of raw milk.
\end{abstract}

Keywords: dairy industry; economic; cost; husbandry; regression analysis.

Practical Application: The study would be helpful in providing decision support to managers for a profitable production of dairy products.

\section{Introduction}

Milk and dairy products are essential food products that are required for the proper growth and development of humans since birth. These are, therefore, considered as an essential foodstuff (Duman, 2003).

Numerous studies highlight that milk and dairy products are basic dietary items that fulfill important functions regarding protection of human health (Lago-Sampedro et al., 2019; Marangoni et al., 2019; Martins et al., 2018).

The functions fulfilled by dairy products as functional goods are mentioned in many studies. It is highlighted that consumption of Probiotic Prato cheese attenuates development of renal calculi (Martins et al., 2018), that L. casei 01-added Probiotic Minas Frescal cheese has desirable effects on the physicochemical and bioactivity characterization and hematological/biochemical parameters of hypertensive overweight women (Sperry et al., 2018), that consumption of yoghurt supplemented with 1000 IU vitamin D by diabetic patients with vitamin D deficiency and hyperlipidemia increases serum lipid indices (Mostafai et al., 2019), and that high-quality goat milk can be used as a carrier for functional components such as prebiotics and bacteria (Verruck et al., 2019).

In Turkey, the dairy industry stands out as one of the most dynamic branches of production in the farming industry (Akın, 2011). A total of $18,655,252$ tons of milk was produced in 2015 , of which $90.8 \%$ comprised cow milk, $6.3 \%$ sheep milk,
$2.6 \%$ goat milk, and $0.3 \%$ water buffalo milk (Türkiye İstatistik Kurumu, 2016).

A large proportion of the milk produced in Turkey is cow milk; $52.2 \%$ of the cow milk produced is processed in industrial plants. Out of the remaining, $21.5 \%$ is used to produce dairy products at home, $10.5 \%$ is directly sold to non-industrial buyers, $8.2 \%$ is consumed directly at home, $5.0 \%$ is used to feed animals, $2.2 \%$ is given free of charge, and $0.4 \%$ is consumed by other uses (Türkiye Ziraat Odaları Birliği, 2011).

According to the data of the Turkish Food and Beverage Industry Inventory, 1,523 businesses operated a milk house and produced cheese in 2012 (Federation of Food and Drink Industry Associatıons of Turkey, 2014). Similarly, the Ministry of Food, Agriculture, and Livestock reported that there were 52 companies that produced pasteurized milk, 31 companies that produced ultra-high temperature (UHT) milk, and 23 companies that produced powdered milk in Turkey in 2012 (Turkey, 2015). In the same year, 790 white cheese producers, 674 kashar cheese producers, and 342 tulum cheese producers were reported. According to another study, 1,772 businesses existed in the Turkish dairy industry in 2012; 268 of these never purchased milk (Güneş, 2013). The businesses in the milk and the dairy product industry, based on the structure and the range of products, can be categorized into dairy farms and small-sized enterprises that produce specific products at specific times in the year. Therefore,

${ }^{1}$ Department of Animal Health Economics and Management, Faculty of Veterinary Medicine, Mehmet Akif Ersoy University, İstiklal Yerleşkesi, Burdur, Turkey

${ }^{2}$ Department of Animal Health Economics and Management, Faculty of Veterinary Medicine, Ankara University, Altındăg, Ankara, Turkey

*Corresponding author: acumhurakin@mehmetakif.edu.tr 
the number of businesses producing a wide range of products throughout the year is small. The most common dairy products produced by the businesses operating in the dairy industry in 2009 and 2012 were white cheese, kashar cheese, yogurt, ayran, and butter (Turkey, 2009, 2015).

The current study determined the production cost of $1 \mathrm{~kg}$ of packaged white cheese, kashar cheese, yogurt, and ayran as well as the financial implication on their distribution and total cost. The study also estimated the effects of the cost factors affecting the profitability of the products by identifying the cost differences between production regions and scales using a mean regression model for each product.

\section{Materials and methods}

\subsection{Data collection}

The present study conducted a questionnaire survey in which 15 dairy plants located in five different regions (I-V) of Turkey agreed to take part. The data for 2013 and 2014 provided by these firms were collected.

\subsection{Choosing the businesses}

The study was restricted to five regions in Turkey with a history of the production of milk and dairy products and that represented the dairy farming and the dairy industry. The study considered various factors such as production structure and diversity, amount of raw material production, proximity to raw materials, marketing channels, geographical location, and population density. The study regions were as follows: Region I: Konya-Karaman-Aksaray, Region II: Ankara-Yozgat-Kırşehir, Region III: Adana-Mersin-Hatay-Gaziantep, Region IV: Burdur-Antalya-Denizli-Izmir, and Region V: Tekirdağ-Bursa-Balıkesir-Istanbul. Within each region, three businesses falling within the small-size (0-50 tons), medium size (51-100 tons), and large size (101 tons and above) categories were included in the study, depending on the amount of raw milk processed in their plants.

\subsection{Data collection}

Face-to-face interviews were conducted with the designated officials of the businesses in the five regions, and the monthly data on white cheese, kashar cheese, yogurt, and ayran production required for the study were collected from the relevant departments of the plants. The content of the questionnaire was based on the questionnaires developed for analysis to be conducted to assess businesses. In this framework, the data collection form consisted of production-related questions about the monthly quantity of raw milk purchased by the businesses, monthly output of each product, and a number of personnel, as well as questions asked to determine the economic, physical, and technical structures and economic activity of the businesses.

\subsection{Evaluating the data}

A cost chart was developed for each product to calculate the production cost of $1 \mathrm{~kg}$ of packaged white cheese, kashar cheese, yogurt, and ayran. The chart included the cost components for the production of each product and the common cost items at the plant. Cost allocation keys were developed based on the quantity of raw milk contained in the products. This helped to allocate the common cost factors in each production month of the plant to the products produced, which were then distributed to the products to determine their unit costs.

\subsection{Statistical analysis}

Analysis of the products' unit costs by regions and plant sizes

The data collected were tested for parametric test assumptions, namely normality and homogeneity of variances using the Kolmogorov-Smirnov and Levene tests, respectively. One-way analysis of variance (ANOVA) was performed to compare the costs on the basis of regions and plant sizes. The differences were tested for statistical significance. Tukey's test, a post-hoc test, was conducted in case a significant difference was found between the unit costs of $1 \mathrm{~kg}$ of packaged white cheese, kashar cheese, yogurt, and ayran on the basis of regions and plant sizes. For all statistical analyses, SPSS 14.01 was used. The probability value used in the statistical evaluations was $p<0.05$.

\section{Regression analysis}

A regression analysis was conducted within the framework of the profit function of each product to reveal the profits earned from the products and the relationship between the variables thought to affect the profits using the data on $1 \mathrm{~kg}$ of packaged white cheese, kashar cheese, yogurt, and ayran for 2013 and 2014.

The function applied in this analysis was formulated as follows in the Equation 1:

$Y=\beta_{0}+\beta_{1} X_{1}+\beta_{2} X_{2}+\beta_{3} X_{3}+\beta_{4} X_{4}+\beta_{5} X_{5}+\beta_{6} X_{6}+\beta_{7} X_{7}+\ldots+\beta_{n} X_{n}$

where $\beta_{0}$ is the constant coefficient and $\beta_{1}, \beta_{2}, \beta_{3} \ldots \beta_{7}$ are the regression coefficients. Each of the $\beta i(i=1,2,3,4,5,6,7)$ coefficients represents the rate of change of the $\mathrm{Y}$ as a function of the change in the relevant independent variable (Özdamar, 2003).

The dependent $(\mathrm{Y})$ and independent variables $(\mathrm{Xn})$ in the regression analysis model for white cheese, kashar cheese, yogurt, and ayran were:

$\mathrm{Y}=$ profit per kilogram (TRY); $\mathrm{X}_{1,2,3,4,5,6,7}=$ labor cost per kilogram (TRY): labor and food expenses; energy cost per kilogram (TRY): electricity, natural gas, and coal expenses; transportation cost per kilogram (TRY): fuel and transportation expenses; unit price of milk (TRY): $1 \mathrm{~kg}$ price of raw milk; raw material used per kilogram $(\mathrm{kg})$ : amount of raw milk in $1 \mathrm{~kg}$ of product; sale price of $1 \mathrm{~kg}$ (TRY): sale price of $1 \mathrm{~kg}$ of the product; packaging cost per kilogram (TRY): and packaging expenses for $1 \mathrm{~kg}$ of the product.

Backward regression analysis was conducted on the model consisting of seven independent variables for $1 \mathrm{~kg}$ of white cheese, kashar cheese, yogurt, and ayran. The models obtained as a result of the analysis are given for the product. 


\section{Results and discussion}

The current study reported the average capacity utilization rate of dairy businesses in Turkey in 2013 and 2014 to be $68.80 \%$. More specifically, the average capacity utilization rate in Turkey in 2012 was $45.52 \%$ for kashar cheese, $51.82 \%$ for white cheese, and $88.39 \%$ for UHT milk (Turkey, 2015). With respect to the monthly changes of the capacity utilization rates of the surveyed businesses in 2013 and 2014, the lowest capacity utilization rate of $63.65 \%$ was reported in January. The supply of raw milk increases in May in Turkey (Food and Agriculture Organization of the United Nations, 2007) with a parallel increase in the capacity utilization rates of the businesses. The capacity utilization rates of the surveyed businesses reach the peak in June and July. In a study conducted in Kurklareli, the average capacity utilization rate of 65 industrial businesses engaged in the production of milk and dairy products was found to be $37.8 \%$. It was noted that $83.11 \%$ of the surveyed dairy industry businesses had a capacity below 30 tons/day (Azabağaoğlu \& İnce, 2004). Another study conducted in Kahramanmaraş in 2011 reported the average capacity utilization rate of 10 businesses engaged in the production of milk and dairy products to be around 31\% (Bars \& Akbay, 2013). The milk and dairy products sub-committee report under the eighth five-year development plan observed the capacity utilization rate to increase from $63 \%$ in 1994 to $70.7 \%$ in 1996 (State Planning Organization, 2001). In a study conducted in Kars in 2006 and 2007, the average capacity utilization rate of 35 dairy farms and dairy industry businesses was calculated to be $31.4 \%$ in 2006 and $31.3 \%$ in 2007 (Demir \& Aral, 2010). Another study by Şahin (1998) conducted on 81 small- and medium-sized businesses operating in the milk and dairy products industry noted the average capacity utilization rate of the businesses to be $61.4 \%$. In a questionnaire survey conducted on four dairy farms in Van in July 2002, Coşkun et al. (2005) reported the capacity utilization rates of the businesses in this province to be very low. As suggested by the previous research, it may be concluded that the capacity utilization rate in the milk and dairy products industry is generally low in Turkey.

The study on dairy industry businesses in each region revealed that the differences between plants of the same size could result in variations to a certain extent between their cost items. This depended on the distance to the supply of raw milk, quality of raw milk, number of personnel, pricing policy, marketing channels, and output.

The average values of the production of 1-kg packages of white cheese, kashar cheese, yogurt, and ayran in 2013 and 2014 suggested that raw material expense was the primary input used in production by the milk and dairy product industry (Table 1). In a previous study, the cost of raw material in the total cost of tulum cheese production was found to be $80.3 \%$ (Dağdemir, 2000). Another study noted the cost of raw milk in the total cost of kashar cheese production to be $71.2 \%$ (Demir, 2009). The cost of raw materials in the total cost of production by the public sector in 1992, as revealed by the Milk and Dairy Products Specialization Committee, was $67.97 \%$ for yogurt production, $66.82 \%$ for white cheese production, and $64.04 \%$ for kashar cheese production, whereas it was $56.7 \%$ for yogurt, $58.2 \%$ for white cheese, and $66.8 \%$ for kashar cheese in the private sector (State Planning Organization, 1995). Another report noted this percentage to be $33.3 \%$ for ayran production, $48 \%$ for yogurt production, $58.9 \%$ for white cheese production, and $50.7 \%$ for kashar cheese production in 1998 in private sector (State Planning Organization, 2001). These differences between the distribution percentages of raw material expenses are directly associated with the price of raw milk and the rate of yield of the businesses at the time.

Dağdemir (2000) noted the percentage of personnel expenses in the total cost of tulum cheese production to be $1.8 \%$. Similarly, another study reported this percentage to be $5.1 \%$ (Demir, 2009). The specialization committees reported the percentage of personnel expenses in the total cost of production by the public sector in 1992 to be $8.08 \%$ for yogurt, $10.46 \%$ for white cheese, and $12.41 \%$ for kashar cheese, whereas the respective percentages in the private sector in the same period were $4.4 \%$, $6.4 \%$, and $10.4 \%$, respectively (State Planning Organization, 1995). This difference between the private-public sectors was clearly observed in this study as well. Another study calculated, though by a different method, that the percentage of partial direct personnel expenses in the total cost was 17\% (Uzun, 2012).

The percentage of packaging expenses in the total cost of production by the private sector in 1992 was $13.4 \%$ for yogurt and $6.8 \%$ for white cheese (State Planning Organization, 1995), whereas the same company reported percentage of packaging expenses in the total cost of production in 1998 to be $21.9 \%$ for

Table 1. Distribution of cost factors of the products in the surveyed businesses for the period between 2013 and 2014.

\begin{tabular}{lcccr}
\hline \multicolumn{1}{c}{ Cost Items } & White Cheese (\%) & Kashar Cheese (\%) & Yogurt (\%) & Ayran (\%) \\
\hline Raw Material Expenses & 71.062 & 73.398 & 68.106 & 54.398 \\
Personnel Expenses & 5.931 & 6.116 & 5.694 & 4.545 \\
Packaging Expenses & 4.744 & 1.807 & 9.000 & 25.715 \\
Transport Expenses & 4.416 & 4.563 & 4.232 & 3.370 \\
Energy Expenses & 3.568 & 3.685 & 3.426 & 2.737 \\
Maintenance/Repair/Depreciation Expense & 2.959 & 3.055 & 2.830 & 2.266 \\
Auxiliary Material Expenses & 1.727 & 1.602 & 0.679 & 0.627 \\
Cleaning/Water Expenses & 1.046 & 1.080 & 1.001 & 0.800 \\
Overhead Expenses & 2.155 & 1.112 & 1.032 & 0.819 \\
Other Manufacturing Expenses & 2.392 & 3.582 & 4.000 & $\mathbf{1 0 0}$ \\
TOTAL COST & $\mathbf{1 0 0}$ & $\mathbf{1 0 0}$ & & $\mathbf{1 0 0}$ \\
\hline
\end{tabular}


ayran, $8 \%$ for yogurt, 3.3\% for white cheese, and 1.5\% for kashar cheese (State Planning Organization, 2001). Furthermore, a study conducted on kashar cheese reported the share of packaging expenses in the total cost to be $1.3 \%$ for small-sized dairy farms, $1.0 \%$ for medium-sized dairy farms, $1.1 \%$ for large-sized dairy farms, and $4.6 \%$ for milk plants (Demir, 2009). The increase in the packaging cost and its share in the total cost of production was attributed to the use of glass bottles and vacuum pumps in the sale of ayran and yogurt, respectively. The results of the current study are similar to the findings of the reports for each product.

The distribution of transportation expenses was found to be uneven leading to higher shares faced by small- and large-sized businesses compared to medium-sized businesses. This could be attributed to the fact that the milk supply points of small-sized businesses are widely distributed, whereas the large-sized businesses procure milk from mostly large farms at remote distances.

Nicholson et al. (2015) in his study conducted in the United States reported that a 7 to $15 \%$ increase in the total distance covered for procuring raw milk may result in a 1 to $2 \%$ increase in the overall cost of the supply chain. Another study noted that the disorganized structure of dairy farming businesses increased the raw milk transportation cost by $20 \%$ (Pimpicki, 1999). Castillo (1990) reported that the insufficient infrastructure of production regions and the distributed structure and remote distance of collection points would increase the costs. It was noted that merging small-sized producers would decrease the transportation costs (Ghosh \& Maharjan, 2002). The study conducted by Demir (2009) found that the average share of the milk collection cost in the total cost of production was $4.2 \%$. The study also reported that the distributed structure of small dairy farming businesses negatively affected the costs. These results are consistent with the results obtained in our study. Another area in which the raw milk collection system in Turkey has been facing a huge problem is quality. The lack of a good collection system for procuring raw milk escalates the costs. It is noted that the milk collection expenses of the dairy industry businesses operating in Turkey has a share of 15 to 20\% in the total cost of production. In France, the milk collection expenses in the west of the country is around 5\% of the average cost of milk (Food and Agriculture Organization of the United Nations, 2007).

With respect to the energy expenses in the total cost of production, large-sized businesses have the highest share, followed by small-sized businesses and medium-sized businesses. The results of this study are similar to the data provided by the specialization committee (State Planning Organization, 1995).

The State Planning Organization report of 1995 mentions the depreciation rates of a private company for 1992 . These were reported to be $3 \%$ for yogurt, 3.1\% for white cheese, and 3.2\% for kashar cheese, whereas these rates were $3.78 \%$ for yogurt, $3.68 \%$ for white cheese, and $2.87 \%$ for kashar cheese in the public sector. These data are consistent with the results of the present study. A study conducted in Kars found that the share of maintenance/repair and depreciation expenses in the total cost of production was $4.3 \%$ for dairy farms and $8.2 \%$ for dairy plants. The higher values found in that study were associated with the low-capacity utilization rate (Demir, 2009).
In the present study, a high depreciation cost was associated with the fact that the medium-sized businesses have more machinery and equipment than small-sized businesses. Also, these have not reached a sufficient level in terms of capacity utilization results.

The inter-relations between various factors, such as the price of raw milk, quality of milk, transportation distances, number of personnel, and wages, are important in determining the production costs. No study could be found that compares the costs of milk and dairy products between regions and plant sizes. With respect to the differences between the unit costs in each region, the costs incurred by the businesses in region $\mathrm{V}$ were higher than those incurred by the businesses in other regions (Table 2). This is attributed to the economic and social structure of that region where costs are increased. The differences between unit costs were found to be statistically significant $(p<0.05)$ when compared with the difference between the unit costs of white cheese and kashar cheese in region $\mathrm{V}$ with the other regions. The major factors responsible for this difference could be the price of raw material and personnel expenses. Additionally, the amount of raw milk going into the manufacturing of the products has an important role in increasing the costs. The costs in region $\mathrm{V}$ were found to be statistically similar $(p<0.05)$ to the cost of yogurt in region II and the cost of ayran in region IV. The reason for this might be the similarity of the costs in the three regions due to factors such as consumer preferences and packaging. Also, the difference in the amount of raw milk used to produce those products did not result in a substantial difference between the three regions.

The lowest unit cost of white cheese was found to be in region III; however, the cost difference was statistically similar to the region I $(p>0.05)$. The businesses in these two regions were not engaged in white cheese production of the same quality as regions IV and $\mathrm{V}$, as a result of which both lower and similar costs were reported in regions I and III.

The lowest unit cost of kashar cheese was found to be in region III. The cost difference between this region and other regions was statistically significant $(p<0.05)$. The lowest unit cost of yogurt was found to be in the region I, which was statistically significant $(p<0.05)$. The lowest unit cost of ayran was found to be in region III. The major reasons for this difference are packaging, the amount of raw milk going into the production, and prices of raw materials. The cost difference between this region and other regions was statistically significant $(p<0.05)$.

Small-sized businesses reported the highest unit costs of all products (Table 3 ). The major reasons underlying this cost disadvantage were the failure to benefit from returns to scale and the idle capacity being greater than that of other businesses. The differences between the unit costs of white cheese and kashar cheese in small-sized enterprises and the unit costs of such products in larger businesses were found to be statistically significant $(p<0.05)$. The unit costs producing yogurt and ayran in small-sized businesses were found to be similar to those in medium-sized businesses $(p>0.05)$ and different than those in large-sized businesses $(p<0.05)$. The cost difference between large-sized businesses and other businesses $(p<0.05)$ was found to be statistically significant. The major factor behind the cost 
Table 2. Statistical comparison of the costs of 1-kg packaged products between regions.

\begin{tabular}{|c|c|c|c|c|c|c|c|c|c|}
\hline & Region & $\mathrm{N}$ & $\begin{array}{c}\text { Arithmetic } \\
\text { Mean }^{*}\end{array}$ & Std. Error & $\begin{array}{c}\text { Std. } \\
\text { Deviation }\end{array}$ & Median & Minimum & Maximum & $\mathrm{p}$ \\
\hline \multirow{5}{*}{$\begin{array}{l}\text { Cost of White } \\
\text { Cheese } \\
(\$ / \mathrm{kg})\end{array}$} & I & 72 & $3.53^{c}$ & 0.09 & 0.40 & 3.52 & 2.66 & 4.37 & $<0.001$ \\
\hline & II & 72 & $4.23^{\mathrm{b}}$ & 0.14 & 0.61 & 4.33 & 3.15 & 5.57 & \\
\hline & III & 72 & $3.50^{\mathrm{c}}$ & 0.06 & 0.28 & 3.55 & 2.81 & 4.11 & \\
\hline & IV & 72 & $4.29^{b}$ & 0.09 & 0.37 & 4.28 & 3.45 & 5.07 & \\
\hline & V. & 72 & $4.48^{\mathrm{a}}$ & 0.06 & 0.24 & 4.46 & 3.90 & 4.96 & \\
\hline \multirow{5}{*}{$\begin{array}{l}\text { Cost of } \\
\text { Kashar Cheese } \\
(\$ / \mathrm{kg})\end{array}$} & I & 72 & $5.76^{c}$ & 0.21 & 0.89 & 5.87 & 4.02 & 7.12 & \\
\hline & II & 72 & $6.77^{\mathrm{b}}$ & 0.25 & 1.07 & 6.88 & 4.97 & 9.32 & \\
\hline & III & 72 & $5.32^{\mathrm{d}}$ & 0.11 & 0.47 & 5.34 & 4.27 & 6.11 & \\
\hline & IV & 72 & $6.81^{\mathrm{b}}$ & 0.14 & 0.61 & 6.66 & 5.60 & 7.91 & \\
\hline & V. & 72 & $7.42^{\mathrm{a}}$ & 0.13 & 0.55 & 7.48 & 6.35 & 8.44 & \\
\hline \multirow{5}{*}{$\begin{array}{l}\text { Cost of Yogurt } \\
(\$ / \mathrm{kg})\end{array}$} & I & 72 & $0.91^{\mathrm{d}}$ & 0.02 & 0.10 & 0.91 & 0.68 & 1.12 & \\
\hline & II & 72 & $1.08^{a}$ & 0.03 & 0.12 & 1.05 & 0.85 & 1.41 & \\
\hline & III & 72 & $0.95^{c}$ & 0.02 & 0.10 & 0.95 & 0.71 & 1.14 & \\
\hline & IV & 72 & $1.00^{\mathrm{b}}$ & 0.02 & 0.08 & 1.01 & 0.81 & 1.15 & \\
\hline & V. & 72 & $1.11^{\mathrm{a}}$ & 0.01 & 0.06 & 1.12 & 0.97 & 1.22 & \\
\hline \multirow{5}{*}{$\begin{array}{l}\text { Cost of Ayran } \\
(\$ / \mathrm{kg})\end{array}$} & I & 72 & $0.45^{c}$ & 0.01 & 0.05 & 0.45 & 0.37 & 0.53 & \\
\hline & II & 72 & $0.57^{\mathrm{b}}$ & 0.01 & 0.05 & 0.57 & 0.48 & 0.68 & \\
\hline & III & 72 & $0.42^{\mathrm{d}}$ & 0.01 & 0.05 & 0.44 & 0.34 & 0.48 & \\
\hline & IV & 72 & $0.62^{\mathrm{a}}$ & 0.01 & 0.04 & 0.62 & 0.54 & 0.68 & \\
\hline & V. & 72 & $0.63^{\mathrm{a}}$ & 0.01 & 0.05 & 0.64 & 0.55 & 0.71 & \\
\hline
\end{tabular}

${ }^{\star}$ Different letters in the same column represent statistical significance $(\mathrm{p}<0.05) . \mathrm{N}=$ Month; Std. $=$ Standard; $\mathrm{p}=\mathrm{p}$-value.

Table 3. Statistical comparison of the costs of 1-kg packaged products between plant sizes.

\begin{tabular}{|c|c|c|c|c|c|c|c|c|c|}
\hline & Sizes & $\mathrm{N}$ & $\begin{array}{c}\text { Arithmetic } \\
\text { Mean* }\end{array}$ & Std. Error & $\begin{array}{c}\text { Std. } \\
\text { Deviation }\end{array}$ & Median & Minimum & Maximum & $\mathrm{p}$ \\
\hline \multirow{3}{*}{$\begin{array}{l}\text { Cost of White } \\
\text { Cheese } \\
(\$ / \mathrm{kg})\end{array}$} & Small & 120 & $4.28^{\mathrm{a}}$ & 0.11 & 0.59 & 4.37 & 3.07 & 5.57 & \multirow[t]{12}{*}{$<0.001$} \\
\hline & Medium & 120 & $4.07^{\mathrm{b}}$ & 0.08 & 0.46 & 4.08 & 3.05 & 5.15 & \\
\hline & Large & 120 & $3.67^{c}$ & 0.09 & 0.49 & 3.58 & 2.66 & 4.63 & \\
\hline \multirow{3}{*}{$\begin{array}{l}\text { Cost of Kashar } \\
\text { Cheese } \\
(\$ / \mathrm{kg})\end{array}$} & Small & 120 & $6.97^{\mathrm{a}}$ & 0.19 & 1.05 & 7.09 & 4.98 & 9.32 & \\
\hline & Medium & 120 & $6.64^{\mathrm{b}}$ & 0.14 & 0.79 & 6.66 & 4.76 & 8.39 & \\
\hline & Large & 120 & $5.64^{c}$ & 0.16 & 0.88 & 5.55 & 4.02 & 7.17 & \\
\hline \multirow{3}{*}{$\begin{array}{l}\text { Cost of Yogurt } \\
(\$ / \mathrm{kg})\end{array}$} & Small & 120 & $1.06^{\mathrm{a}}$ & 0.02 & 0.11 & 1.08 & 0.82 & 1.31 & \\
\hline & Medium & 120 & $1.04^{\mathrm{a}}$ & 0.02 & 0.11 & 1.05 & 0.80 & 1.41 & \\
\hline & Large & 120 & $0.93^{b}$ & 0.02 & 0.11 & 0.93 & 0.68 & 1.13 & \\
\hline \multirow{3}{*}{$\begin{array}{l}\text { Cost of Ayran } \\
(\$ / \mathrm{kg})\end{array}$} & Small & 120 & $0.57^{\mathrm{a}}$ & 0.02 & 0.11 & 0.59 & 0.37 & 0.71 & \\
\hline & Medium & 120 & $0.56^{\mathrm{a}}$ & 0.01 & 0.08 & 0.58 & 0.42 & 0.68 & \\
\hline & Large & 120 & $0.49^{b}$ & 0.02 & 0.09 & 0.52 & 0.34 & 0.62 & \\
\hline
\end{tabular}

${ }^{\star}$ Different letters in the same column represent statistical significance $(\mathrm{p}<0.05) . \mathrm{N}=$ Month; Std. $=$ Standard; $\mathrm{p}=\mathrm{p}$-value.

advantage of large-sized businesses was the decrease in costs with the increase in the scale of production.

Table 4 shows the relationship between the profit per unit of the product (assumed to be constant in the model developed with the independent variables whose effect on profit $(\mathrm{Y})$ was found to be statistically significant) and the independent variables to be as anticipated.

Previous studies conducted in this field in Turkey were statistically insufficient. The explanatory power of the $R^{2}$ value of the profitability model in the study by Demir \& Aral (2010) is lower than that of our model. Also, the order of the powers of independent variables to affect the dependent variable differs in the two studies.
It can be said that the findings obtained from this study are generally consistent with the previous studies and reports, and reflect the unit costs in the dairy industry. In other words, the study obtained results that can help explaining the dairy industry in terms of both the cost distribution and the regional production patterns. The results also highlight that the differences at regional and business level stem from partial differences arising out of production technologies, quality perception, hygiene and market conditions that change periodically. Furthermore, it was found that in the regression models developed with the independent variables whose effect on unit profit of dairy products was found to be statistically significant, the relationship between the unit profit of the fixed product and the independent variables was as expected. 
Table 4. The results of the regression analysis for the estimated profit from certain products of the businesses.

\begin{tabular}{|c|c|c|c|c|c|c|c|c|c|c|c|c|}
\hline & Parameters & & $\mathrm{N}$ & $\beta$ & Std. Error & $\mathrm{t}$ & Sig. & Adj. $R^{2}$ & $\mathrm{~F}$ & Sig. F & Tolerance & VIF \\
\hline White & Constant & & 360 & -0.307 & 0.045 & -6.838 & $<0.001$ & 0.921 & 697.737 & $<0.001$ & & \\
\hline \multirow[t]{6}{*}{ Cheese } & Personnel & $\mathrm{X}_{1}$ & & -0.163 & 0.007 & -22.223 & & & & & 0.692 & 1.444 \\
\hline & Energy & $\mathrm{X}_{2}$ & & -0.153 & 0.011 & -13.897 & & & & & 0.825 & 1.213 \\
\hline & Transportation & $\mathrm{X}_{3}$ & & -0.079 & 0.011 & -7.552 & & & & & 0.632 & 1.581 \\
\hline & Price of Milk & $\mathbf{X}_{4}$ & & -0.979 & 0.071 & -13.846 & & & & & 0.361 & 2.773 \\
\hline & Raw Material & $\mathbf{X}_{5}$ & & -0.686 & 0.049 & -14.12 & & & & & 0.561 & 1.782 \\
\hline & Sales Price & $X_{6}$ & & 1.575 & 0.049 & 31.94 & & & & & 0.304 & 3.289 \\
\hline \multirow{7}{*}{$\begin{array}{l}\text { Kashar } \\
\text { Cheese }\end{array}$} & Constant & & 360 & -0.302 & 0.071 & -4.266 & $<0.001$ & 0.874 & 417.604 & $<0.001$ & & \\
\hline & Sales Price & $\mathrm{X}_{1}$ & & 1.580 & 0.061 & 25.997 & & & & & 0.357 & 2.799 \\
\hline & Personnel & $\mathrm{X}_{2}$ & & -0.199 & 0.011 & -18.606 & & & & & 0.584 & 1.711 \\
\hline & Energy & $\mathbf{X}_{3}$ & & -0.167 & 0.016 & -10.333 & & & & & 0.751 & 1.331 \\
\hline & Transportation & $\mathrm{X}_{4}$ & & -0.114 & 0.014 & -7.928 & & & & & 0.632 & 1.582 \\
\hline & Raw Material & $\mathbf{X}_{5}$ & & -0.632 & 0.062 & -10.192 & & & & & 0.454 & 2.203 \\
\hline & Price of Milk & $\mathrm{X}_{6}$ & & -0.924 & 0.086 & -10.7 & & & & & 0.467 & 2.142 \\
\hline \multirow[t]{8}{*}{ Yogurt } & Constant & & 360 & -0.645 & 0.014 & -47.294 & $<0.001$ & 0.973 & 1843.363 & $<0.001$ & & \\
\hline & Personnel & $\mathrm{X}_{1}$ & & -0.083 & 0.003 & -30.468 & & & & & 0.757 & 1.322 \\
\hline & Energy & $\mathrm{X}_{2}$ & & -0.087 & 0.004 & -19.875 & & & & & 0.794 & 1.259 \\
\hline & Transportation & $\mathbf{X}_{3}$ & & -0.025 & 0.004 & -5.975 & & & & & 0.650 & 1.539 \\
\hline & Price of Milk & $\mathrm{X}_{4}$ & & -0.589 & 0.025 & -23.866 & & & & & 0.429 & 2.331 \\
\hline & Raw Material & $\mathbf{X}_{5}$ & & -0.349 & 0.016 & -21.707 & & & & & 0.861 & 1.161 \\
\hline & Sales Price & $\mathrm{X}_{6}$ & & 1.487 & 0.020 & 75.321 & & & & & 0.316 & 3.160 \\
\hline & Packaging & $\mathbf{X}_{7}$ & & -0.115 & 0.007 & -17.442 & & & & & 0.668 & 1.497 \\
\hline \multirow[t]{8}{*}{ Ayran } & Constant & & 360 & -0.376 & 0.009 & -42.523 & $<0.001$ & 0.968 & 1551.925 & $<0.001$ & & \\
\hline & Personnel & $\mathrm{X}_{1}$ & & -0.039 & 0.004 & -10.851 & & & & & 0.467 & 2.139 \\
\hline & Transportation & $\mathrm{X}_{2}$ & & -0.029 & 0.005 & -6.536 & & & & & 0.580 & 1.724 \\
\hline & Energy & $\mathrm{X}_{3}$ & & -0.048 & 0.005 & -9.728 & & & & & 0.740 & 1.352 \\
\hline & Raw Material & $\mathrm{X}_{4}$ & & -0.420 & 0.013 & -32.744 & & & & & 0.529 & 1.892 \\
\hline & Price of Milk & $X_{5}$ & & -0.322 & 0.027 & -11.804 & & & & & 0.435 & 2.298 \\
\hline & Sales Price & $X_{6}$ & & 0.903 & 0.017 & 52.228 & & & & & 0.365 & 2.742 \\
\hline & Packaging & $\mathrm{X}_{7}$ & & -0.208 & 0.009 & -22.816 & & & & & 0.554 & 1.806 \\
\hline
\end{tabular}

$\mathrm{N}=$ Month; Adj. $\mathrm{R}^{2}$ = Adjusted R Squared; VIF = Variance İnflation Factor; Sig. = Significance; Sig. F = Significance F.

\section{Conclusion}

The profitability of dairy industry businesses depends on minimizing the cost of items constituting the total cost of producing milk and dairy products. On the other hand, the low-capacity utilization rates observed in the present study negatively affect the production costs. The effect of returns to scale on the costs was observed in field conditions. To earn higher profits, it is important for businesses to increase the scale of their production and keep it at an optimum level. Regional differences, in terms of costs, might arise, depending on the quality and content of products, consumer preferences, economic welfare level of the region, and density of raw milk producers. The regression analyses showed the sales price and the price of raw milk to be major factors affecting the profitability of products for white cheese, kashar cheese, and yogurt. However, for ayran, the sales price is followed by the amount of raw milk contained in the product. In conclusion, this study indicates that the businesses need to take into account the cost of items for a sustainable production and their effects on the businesses from the perspective of business administration.

\section{Acknowledgements}

This study is summarised from Ahmet Cumhur AKIN's $\mathrm{PhD}$ thesis. This research is supported as project no. 14L0239003 by Ankara University Directorate of Scientific Research Projects.

\section{References}

Akın, A. C. (2011). AB ve Türkiye süt sektörlerinin ekonomik yönden karşılaştırılması. In AB Uyum Sürecinde Türkiye Hayvancılık Kongresi 2011 (Uluslararası Katılıml). Kızılcahamam-Ankara, Türkiye.

Azabağaoğlu, M. Ö., \& İnce, F. (2004). Kırklareli ilinde süt sanayinin durumu. Tarim Bilimleri Dergisi, 10, 323-326. http://dx.doi. org/10.1501/Tarimbil_0000000914. 
Bars, T., \& Akbay, C. (2013). Kahramanmaraş ilinde süt ve süt ürünleri işleyen mandıra işletmelerinin yapısal analizi. Kahrmanmaraş Sütçü İmam Üniversitesi Doğa Bilimleri Dergisi, 16, 9-20.

Castillo, L. B. (1990). Milk collection systems, handbook on milk collection in warm developing countries IDF (Special Issue, No. 9002). Belgium.

Coşkun, H., Tunçtürk, Y., Altındağ, S., \& Demir, A. (2005). Van’a faaliyet gösteren süt işletmelerinin mevcut durumları, sorunları ve çözüm önerileri. Yüzüncü Yıl Üniversitesi Ziraat Fakültesi Tarım Bilimleri Dergisi, 15, 11-15.

Dağdemir, V. (2000). Erzincan ilinde tulum peynirinin imalat maliyeti ve pazarlama marjının belirlenmesi üzerine bir araştırma. Turkish Journal of Agriculture and Forestry, 24, 57-61.

Demir, P. (2009). Kars ili süt sanayi işletmelerinde üretim ve sanayi entegrasyonunun ekonomik ve sosyo-ekonomik analizi (Doktora tezi). Ankara Üniversitesi Sağlık Bilimleri Enstitüsü, , Ankara.

Demir, P., \& Aral, S. (2010). Kars ili süt sanayi işletmelerinde üretim ve sanayi entegrasyonunun ekonomik ve sosyo-ekonomik analizi. Kafkas Üniversitesi Veteriner Fakültesi Dergisi, 16, 585-592.

Duman, S. G. (2003). Türkiye süt endüstrisinin sektörel analizi (Doktora tezi). Uludağ Üniversitesi Fen Bilimleri Enstitüsü, Bursa.

Federatıon of Food and Drınk Industry Associatıons of Turkey. Türkiye Gıda ve İçecek Sanayii Dernekleri Federasyonu - TGDF. (2014). Türk gida ve içecek sanayi envanteri 2014. Ankara.

Food and Agriculture Organization of the United Nations - FAO. (2007). AB giriş süreci çerçevesinde Türkiye’de süt ve süt ürünleri sektörüne genel bakış. Roma: FAO.

Ghosh, A. K., \& Maharjan, K. L. (2002). Milk marketing channels in Bangladesh: a case study of three villages from three districts. Journal of International Development and Cooperation, 8, 87-101.

Güneş, E. (2013). Süt sektöründe pazar ve pazarlama yapisi II. İzmir: Ulusal Süt Zirvesi.

Lago-Sampedro, A., García-Escobar, E., Rubio-Martín, E., PascualAguirre, N., Valdés, S., Soriguer, F., Goday, A., Calle-Pascual, A., Castell, C., Menéndez, E., Delgado, E., Bordiú, E., Castaño, L., FranchNadal, J., Girbés, J., Chaves, F. J., Gaztambide, S., Rojo-Martínez, G., \& Olveira, G. (2019). Dairy product consumption and metabolic diseases in the di@bet.es study. Nutrients, 11(2), 262. http://dx.doi. org/10.3390/nu11020262. PMid:30682848.

Marangoni, F., Pellegrino, L., Verduci, E., Ghiselli, A., Bernabei, R., Calvani, R., Cetin, I., Giampietro, M., Perticone, F., Piretta, L., Giacco, R., La Vecchia, C., Brandi, M. L., Ballardini, D., Banderali, G., Bellentani, S., Canzone, G., Cricelli, C., Faggiano, P., Ferrara, N., Flachi, E., Gonnelli, S., Macca, C., Magni, P., Marelli, G., Marrocco, W., Miniello, V. L., Origo, C., Pietrantonio, F., Silvestri, P., Stella, R., Strazzullo, P., Troiano, E., \& Poli, A. (2019). Cow's milk consumption and health: a health professional's guide. Journal of the American College of Nutrition, 38(3), 197-208. http://dx.doi.org/10.1080/073 15724.2018.1491016. PMid:30247998.

Martins, A. A., Santos-Junior, V. A., Tavares, E., Fo., Silva, H. L., Ferreira, M. V. S., Graça, J. S., Esmerino, E. A., Lollo, P. C. B., Freitas, M. Q., Sant'Ana, A. S., Costa, L. E. O., Raices, R. S. L., Silva, M. C., Cruz, A. G., \& Barros, M. E. (2018). Probiotic Prato cheese consumption attenuates development of renal calculi in animal model of urolithiasis. Journal of Functional Foods, 49, 378-383. http://dx.doi.org/10.1016/j. jff.2018.08.041.
Mostafai, R., Nachvakc, S. M., Mohammadi, R., Rocha, R. S., da Silva, M. C., Esmerino, E. A., Nascimento, K. O., Cruz, A. G., \& Mortazavian, A. M. (2019). Effects of vitamin D-fortified yogurt in comparison to oral vitamin D supplement on hyperlipidemia in pre-diabetic patients: a randomized clinical trial. Journal of Functional Foods, 52, 116-120. http://dx.doi.org/10.1016/j.jff.2018.10.040.

Nicholson, C. F., He, X., Gómez, M. I., Gao, H. O., \& Hill, E. (2015). Environmental and economic impacts of localizing food systems: the case of dairy supply chains in the Northeastern United States. Environmental Science \& Technology, 49(20), 12005-12014. http:// dx.doi.org/10.1021/acs.est.5b02892. PMid:26401757.

Özdamar, K. (2003). SPSS ile biyoistatistik: yenilenmiş 5. Eskişehir: Kaan Kitabevi.

Pimpicki, S. (1999). Factors affecting changes in the raw material transportation schedule at a dairy plant. Poland: Wydawnictwo Akademii Ekonomicznej we WrocLawiu.

Şahin, K. (1998). Süt ve süt mamulleri sanayinde küçük ve orta ölçekli işletmelerin yapısı, sorunları ve çözüm yolları (Doktora tezi). Çukurova Üniversitesi Fen Bilimleri Enstitüsü, Adana.

Sperry, M. F., Silva, H. L., Balthazar, C. F., Esmerino, E. A., Verruck, S., Prudencio, E. S., Neto, R. P. C., Tavares, M. I. B., Peixoto, J. C., Nazzaro, F., Rocha, R. S., Moraes, J., Gomes, A. S. G., Raices, R. S. L., Silva, M. C., Granato, D., Pimentel, T. C., Freitas, M. Q., \& Cruz, A. G. (2018). Probiotic Minas Frescal cheese added with L. casei 01: physicochemical and bioactivity characterization and effects on hematological/biochemical parameters of hypertensive overweighted women: a randomized double-blind pilot trial. Journal of Functional Foods, 45, 435-443. http://dx.doi.org/10.1016/j.jff.2018.04.015.

State Planning Organization. (1995). 7. Beş Yıllık Kalkınma Planı Gıda Sanayii Özel İhtisas Komisyonu Raporu Süt ve Süt Ürünleri Sanayii Alt Komisyon Raporu. Ankara.

State Planning Organization. (2001). 8. Beş Yıllık Kalkınma Planı Gıda Sanayii Özel İhtisas Komisyonu Raporu Süt ve Süt Ürünleri Sanayii Alt Komisyon Raporu. Ankara.

Turkey. Minıstry of Food, Agriculture and Livestock - MoFAL. (2009). Gıda Tarım ve Hayvancılık Bakanlı̆̆ 2009 yılı Gıda Sanayi Envanteri Raporu. Ankara.

Turkey. Minıstry of Food, Agrıculture and Livestock - MoFAL. (2015). Gıda Tarım ve Hayvancılık Bakanlı̆̆ gıda sanayi işletme verileri. Ankara.

Türkiye İstatistik Kurumu - TURKSTAT. Hayvancılık İstatistikleri Veri Tabanı. (2016). Üretilen toplam çiğ süt miktarı. Retrieved from https://biruni.tuik.gov.tr/hayvancilikapp/hayvancilik.zul

Türkiye Ziraat Odaları Birliği - TZOB. (2011). Zirai ve İktisadi Rapor 2007-2010. Ankara: Aydoğdu Ofset.

Uzun, Ö. (2012). Üretim işletmelerinde safha maliyet sisteminin önemi Aydın ilinde süt ve süt ürünleri işletmesinde örnek bir uygulama (Yüksek lisans tezi). Adnan Menderes Üniversitesi Sosyal Bilimler Enstitüsü, Aydın.

Verruck, S., Dantas, A., \& Prudencio, E. S. (2019). Functionality of the components from goat's milk, recent advances for functional dairy products development and its implications on human health. Journal of Functional Foods, 52, 243-257. http://dx.doi.org/10.1016/j. jff.2018.11.017. 